\title{
DIŞ TİCARET YAPAN FİRMALARIN KUR RİSKİNE KARŞI KORUNMA YÖNTEMLERİ: MALATYA ÖRNEĞİ*
}

\section{METHODS OF HEDGING AGAINST CURRENCY RISK OF FOREIGN TRADE COMPANIES: THE CASE OF MALATYA}

\author{
Ahmet ŞíT ${ }^{1}$ \\ Mehmet Cem DANACI ${ }^{2}$
}

$\ddot{O} z$

Bu çalışmanın amacı Malatya ilinde dış ticaret yapan firmalarından döviz kur riskine karşı korunma durumlarının araştırılmasıdır. Dış ticaret yapan firmalar için yönetim riski, pazar riski vb risklerinin yanı sıra özellikle esnek döviz kuru politikasını benimseyen ülkelerde kur riski daha önemlidir. Türkiye’nin yıllar itibari ile ihracat hasılatı artmaktadır. Özellikle tarım ürünleri ihracatı da ihracatta öneli bir yer tutmaktadır. Bu amaçla Malatya dış ticaret yapan 55 firmaya anket çalışması uygulanmıştır. Anket soruları Pearson korelâsyon ve çoklu doğrusal regresyon analizleri yöntemleriyle analiz edilmiştir. Çalışma sonucunda anket çalışmasına katılan firmaların \% 62 'sinin döviz kur riskine karşı herhangi bir korunma yöntemi olmadiğl, döviz kur riskine karşı korunma yöntemleri benimseyen firmaların faaliyet süresine, ankete katılanların eğitim durumuna göre anlamlı farklılık gösterdiği; döviz kur riskine karşı korunma yöntemleri olmayan firmaların firma büyüklüğüne, faaliyetlerinden dış ticaret oranına, firmanın hukuki yapısına göre anlamlı farklılık gösterdiği görülmüştür.

Anahtar Kelimeler: Dış Ticaret, Döviz Kur Riski, Malatya, Korelasyon Analizi, Regresyon Analizi Jel Kodlar: F14, F31, G32

\section{Abstract}

The aim of this study is to investigate the protection status of foreign trade companies against exchange rate risk in Malatya. For foreign trade companies, in addition to management risk, market risk, etc., currency risk is more important, especially in countries that adopt a floating exchange rate policy. Turkey's export revenue has been increasing over the years. In particular, the export of agricultural products has an important place in exports. For this purpose, a questionnaire study was applied to 55 companies engaged in foreign trade in Malatya. Questionnaire questions were analyzed using Pearson Correlation and multiple linear Regression analysis methods. As a result of the study, it was determined that $62 \%$ of the companies participating in the survey did not have any hedging method against exchange rate risk, that companies that adopted hedging methods against exchange rate risk differed significantly according to the duration of their activities and the education level of the survey participants; It has been observed that companies that do not have hedging

\footnotetext{
* Bu çalışma İnönü Üniversitesi BAP Birimi tarafından fonlanan ve2020 yılında tamamlanan SBA-2018-1155 numaralı BAP projesi sonuç raporundan türetilmiştir.

${ }^{1}$ Dr. Öğr. Üyesi, Malatya Turgut Özal Üniversitesi Sosyal ve Beşeri Bilimler Fakültesi Uluslararası Ticaret ve Finansman Bölümü, ahmet.sit@ ozal.edu.tr, ORCID: 0000-0002-0257-9023

2 Dr. Öğr. Üyesi, İnönü Üniversitesi, İktisadi ve İdari Bilimler Fakültesi İşletme Bölümü, memetcem.danaci@inonu.edu.tr, ORCID: 0000-0003-0930-7909
} 
methods against exchange rate risk differ significantly according to the size of the firm, its activities to foreign trade ratio, and the legal structure of the firm.

Keywords: ForeignTrade, Currency Risk, Malatya, CorrelationAnalysis, Regression Analysis

Jel Classification $\quad$ : F14, F31, G32

\section{GíRiș}

Ülke ekonomileri açısından önemli dinamiklerin başında ihracat ve ithalat gelmektedir. Zira ülkelerin ödemeler bilançosu dengesinde dış ticaretin önemli bir ağırlığı olduğu bilinmektedir. İthalat ve ihracat yapan firmalar için faaliyet gösterdikleri ülkedeki kur sistemi büyük önem arz etmektedir.

Özellikle 20. yüzyılın sonlarına doğru Bretton Woods sabit kur sisteminin çöküşüyle birlikte piyasalarda döviz fiyatlarında hareketlilik artmıştır (Ünal ve Altın, 2010:1). Esnek kur sisteminin faaliyet hacimleri içerisinde ithalat/ihracatın önemli payı olan firmaların karşılaştıkları birçok riskin yanında karşılaşacakları en önemli risklerden biri de kur riskidir. İşletmelerin kur riskini doğru yönetebilmesi durumunda kur riskinden etkilenmeyecektir ya da çok az etkilenecektir.

Kur riski yönetiminde işletmeler türev ürünler kullanarak, sigorta yaptırarak ve buna benzer yöntemlerle kur riskine karşı korunmaktadır. Bu nedenle döviz kur riski yönetim araçları hem uluslararası piyasalar açısından hem de faaliyetleri ve faaliyetlerinin mali tablolara yansımasından dolayı etkilenecektir (Çıtak ve Kurt, 2020). Bu etkilenme firmaların finansal tablolarına olumlu/olumsuz kur farkı olarak yansıyacaktır.

Bu çalışmada Malatya ilinde faaliyet gösteren dış ticaret firmalarının döviz kuru riskine karşı kur riskinin önlenmesinde korunma yöntemlerinin olup olmadığı konusu araştırılmıştır. Çalışmada örneklem şehir olarak Malatya'nın seçilmesinin nedeni, Türkiye'nin kayısı, kiraz, elma gibi bazı tarım ürünlerinin ihracatında ve tekstil üretiminde Malatya'nın önemli bir payının olması Türkiye ortalamasının üzerinde olması, özelikle tekstil ürünlerinin ve kayısının büyük kısmının ihracat yapılmasıdır. Bu çerçevede Malatya ilinde dış ticaret yapan 55 firmaya anket çalışması uygulanmıştır. Yöntem olarak Pearson korelâsyon ve çoklu doğrusal regresyon analizleri tercih edilmiştir.

\section{LITERATÜR TARAMASI}

$\mathrm{Bu}$ çalışmanın konusu Malatya'da faaliyet gösteren dış ticaret firmalarının kur riskine karşı korunma yöntemlerinin araştırılmasıdır. Ayrıca ihracat ile işletmeler daha yüksek fiyatlara satış yapabilmekte ve nakit döviz girdisi sağlayabilmektedir. Ya da ülkelerin yurt içinde ürettikleri ürünlerin fazla olması yani arz fazlası olması durumunda yeni pazarlara sevk etmektedir. İşletmeler yurtiçine satış yaptıkları gibi toplam satış hasılatları içinde dış ticaretin payı da her geçen gün artmaktadır. Dış ticarette alışverişin ulusal para dışında yabancı paralarla yapılması ülkeleri kur riski ile karşı karşıya bırakmaktadır. Dış ticaret firmalarının kur riskine karşı korunma yöntemleriyle ilgili ulusal ve uluslararası literatürde yapılan çalışmalar incelenecektir: 
Kim vd. (2020), döviz kuru riskinin azaltılmasında dış borç kullanımının etkisini Kore için araştırmışlardır. Çalışmada çok uluslu işletmeler ile ihracatçı firmaları karşılaştırmıştır. Elde edilen bulgularda dış borçların kur riskine karşı koruma etkinliğinin ihracatçı firmalara kıyasla ithalatçı firmalarda daha belirgin olduğu görülmektedir.

Gonzalez vd. (2010), döviz kuru riskinden korunma aracı olarak dış borçları İspanya'da 96 finansal olmayan firma için incelemişlerdir. Dış borçla korunma kararının döviz riskine maruz kalma, büyüklük, ileriye dönük vergi kaybı, yönetimsel riskten kaçınma ve inşaat, Ar-Ge ve diğer hizmetler sektörü ile pozitif ilişkili olduğu tespit edilmiştir. Ayrıca, riskten korunma kapsamı; döviz riskine maruz kalma, büyüklük, yönetimsel riskten kaçınma ile pozitif ve finansal sıkıntı maliyetleri ile negatif ilişkili olduğunu tespit etmişlerdir. Ayrıca, para swaplarının varlığını ve türünü kontrol ettikten sonra, bu değişkenin döviz borcu ile korunmanın belirleyicileri üzerinde bir etkisinin olmadığını ortaya koymuşlardır.

Papaioannou (2006), döviz kuru riskinin ölçülmesi ve yönetilmesinin bir firmanın kar marjlarını ve varlıklarının değerini olumsuz yönde etkileyebileceğini ifade etmiştir. Bu noktadan hareketle büyük döviz kuru hareketlerinden kaynaklanan kırılganlıklarını azaltma amacından hareketle yaptıkları çalışmalarında VAR yöntemini kullanmışlardır. Binom probit tahmin değerlerine bakıldığında kur riskinin firmalar için oldukça önemli olduğu ve kur riskinden korunmak için gerekli önlemlerin alınması gerektiği ortaya çıkmıştır. Bu önlemlerinde başında hedging enstrümanı olan türev ürünler gelmektedir.

Firmaların yabancı para türevlerini döviz kuru riskinden korunma amacıyla mı yoksa spekülatif amaçlarla mı kullanıldığını araştıran Allayannis ve Ofek (2001) 1993 yılı için S\&P 500 içinde yer alan finansal olmayan firmalardan oluşan bir örnek kullanmışlardır. Çalışmada OLS regrsyon ve probit tahminci yöntemleri kullanılmıştır. Elde edilen bulgularda firmaların kur riskinden korunmak için türev ürünler kullandıklarına dair kanıtlara ulaşılmıştır. Çünkü firmaların döviz türevlerini kullandıklarında karşı karşıya kaldıkları kur riskini önemli ölçüde azalttıkları tespit edilmiştir.

Döviz kurlarındaki oynaklığın ve belirsizliğin uluslararası portföylerin performansını olumsuz etkilediğinden hareketle Eun ve Resnick (1988), döviz kuru riskini ve korunma yöntemlerini ABD için incelemişlerdir. Sonuç olarak kur riskini önlemek için iki yöntemin öne çıktığı söylenebilir. Bunlardan ilki farklı para birimlerinden çeşitlendirme diğeri ise vadeli döviz sözleşmeleri ile korunmadır.

Firmaların kur riskine karşı korunma yöntemleriyle ilgili Türkiye üzerine yapılan çalışmalardan Aksu (2016), 2005-2014 dönemi verileriyle imalatçı firmalarda kur riskinin etkilerini mali veriler, rasyo analizi ve trend analizi ile incelemiş ve kur riskine karşı çözüm önerileri ortaya koymuştur. Çalışmanın sonucunda imalat firmalarının kur riskinden korunabilmeleri için döviz cinsinden faturalandırma, kurdaki hareketin fiyata yansitılması, operasyonel ve finansal hedging olarak 4 temel enstrümanı olduğu ifade edilmektedir. 
Aksüyek ve Yılmaz (2017), döviz kuru riskinin dış ticaret yapan tüm işletmeleri etkilediği gibi inşaat sektöründe çalışan işletmelerin de karlılığını önemli ölçüde etkilediğini, buradan hareketle kur riskinin inşaat projeleri üzerindeki etkisini ve korunma yöntemlerini araştırmışlardır. Gerçekleşmiş örnek projeler üzerinden yapılan maliyet ve kar hedeflerini gösteren karşılaştırmalı tablolarda sistematik olan kur riskinin inşaat sektöründeki firmaları ciddi bir şekilde etkilediği görülmektedir. Kur riskinden korunmak için de şirketlerin hedging yöntemlerinden forward, futures, swap ve opsiyon sözleşmeleri gibi türev ürünlerden faydalanmaları gerektiği vurgulanmıştır.

Benzer bir diğer çalışmada Sezer ve Canpolat (2017), kur riskinden korunma yöntemlerinden türev ürünlerin kullanımının şirketlerin dış ticareti ve mevduatları açısından önemini ortaya koymak için uygulama örnekleri incelemişlerdir. Elde edilen bulgularda türev ürün kullanımının kur riskinden korunmada oldukça etkili olduğu vurgulanmaktadır. Ancak gelişmiş ülkelere klyasla Türkiye'de türev ürünlerin kullanımının oldukça yetersiz olduğu ve artırılmasının önemli olduğu vurgulanmaktadır.

Kur riski yönetimini temsili bir Türk dış ticaret firması için inceleyen Çiftçi ve Yıldız (2013), çalışmalarında firmanın uluslararası para piyasası ve döviz piyasası yoluyla riske karşı korunma tedbirine başvurduğunu ve her iki yöntemin de önemli koruma sağladığını ortaya koymuşlardır. Aynı zamanda bu tekniklerin döviz açı pozisyonda olan firmalarca kullanımının özendirilmesi ve farkındalığın artırılması gerektiğini belirtmişlerdir.

Kur riskinden korunmada "Range Forward" yöntemini kullanan çalışmalarında Aypek ve Kayahan (2010), önceden belirlenen çeşitli senaryolar altında uygulanma alternatiflerini ve portföy üzerindeki olası etkilerini incelemişlerdir. Kur riskine karşı en etkili yöntemin forward sözleşmeler olduğu ancak bu sözleşmelerin taraflara çok az esneklik sunduğu bu nedenle gelişmiş ülkelerde range forward ve participating forward gibi özellikli sözleşmelerin ortaya çıktığı belirtilmiştir. $\mathrm{Bu}$ sözleşmeler genellikle belirli bir fiyat aralığındaki fonların uzlaştırılmasını sağlamak için kullanılmaktadır (Investopedia, 2021). Range forwardda düşük oran, Türk Lirası'na karşı ilgili döviz kurunun değer kaybetmesiyle meydana gelebilecek kayılardan korunma imkânı verir. Tavan oranın yüksek olması ise, Türk Lirası'na karşı ilgili döviz kurunun değer kazanmasıyla oluşacak olan muhtemel kayıpları engeller (Aypek ve Kayahan, 2010:10) . Bu sözleşmelerin kur riskinden korunmada oldukça etkili olduğu vurgulanmaktadır.

Kayahan vd. (2010), çalışmalarında Türkiye reel sektörünün kur riskinden korunmasında türev ürünlerden opsiyon kontratlarının kullanılmasını incelemişlerdir. Opsiyon kontratlarının alıcısına diğer hedging yöntemlerine göre daha esneklik ve farklı seçenekler sunduğundan kur riskine karş1 korunmada önemli olduğu vurgulanmaktadır. Aynı zamanda 2007-2008 dönemi aylık ve üç aylık veriler incelendiğinde reel sektörün opsiyon kullanımında en dikkat ettiği konu prim seviyesidir. Prim ise algılanan volatiliteye bağlı olarak değişmekte ve korunma maliyetini de artırmaktadır. 
Turizm sektörü için döviz kuru riski ve korunma yöntemlerini inceleyen Kutukız (2005), Muğla bölgesinde yer alan genellikle KOBİ sınıflandırmasına dahil olabilecek 120 firmaya anket çalışması yapmıştır. Amacı firmalarda hangi risklerin daha ağırlıklı olduğu ve bu risklere karşı işletmelerin tedbir alıp almadığını test etmektir. Çalışma sonucunda 2001 y1lı öncesinde firmalar; kendilerini etkileyen en önemli riskin faiz riski olduğunu ifade ederken 2001 sonrası en önemli riskin döviz kur riski olduğunu ifade etmişlerdir. Ayrıca bu firmaların kur riskine karşı vadeli işlem yapmadıkları, hatta türev ürünler hakkında bilgi sahibi olmadıkları ifade edilmiştir. Ayrıca 2003 yılı öncesinde TL'nin yabancı para karşısında değer kaybetmesi dolayısı ile bankadaki mevduatların döviz ağırlıklı olduğu, bu yıldan sonra mevduatlarda TL'nin payının arttığı görülmektedir.

Çalışmanın literatürde yer alan çalışmalardan farkı uygulandığı örneklemdir. Yani bu konuda daha önce Malatya ili özelinde böyle bir çalışma olmaması, yöntemin farklı olması ve elde edilen sonuçların kuramsal çerçeveyle desteklenmesi çalışmanın özgünlüğünü ortaya koymaktadır.

\section{UYGULAMA VE ANALIZ}

Çalışmanın bu kısmında Malatya ilinde dış ticaret yapan firmalara uygulanan anket soruları analiz edilecektir. Toplamda 62 işletmeye anket çalışması yapılmış, 55 firmadan anket çalışmasına katılım olmuştur. Yani katılım oranı \%89'dur.

\section{1. Çalışmanın Amacı}

$\mathrm{Bu}$ çalışmada Malatya ilinde faaliyet gösterip dış ticaret yapan firmaların döviz kur riskine karşı korunma yöntemleri araştırılmıştır. Bu amaçla 55 firmaya anket çalışması uygulanmıştır.

\section{2. Çalıșmanın Modeli ve Yöntemi}

Araştırmada döviz kuru riskinden korunan ve korunmayan firmalar bağımlı değişken olarak ele alınmış ve demografik özelliklere göre ortaya çıkan etki ve ilişkisi araştırılmıştır. Araştırma kapsamında toplanan verilerle öncelikle örneklem grubunun demografik özelliklerinin görülebilmesi için betimleyici istatistik ve frekans analizleri kullanılmıştır. Anketin hazırlanmasında Ketboğa (2020) çalışmasında kullanılan anket ölçeğinden yararlanılmıştır. Elde edilen veriler SPSS programlarından yararlanılarak yapılan frekans analizleri, güvenilirlik testleri, Varyans Analizi (Anova), Bağımsız Örneklem Testi (T-testi), Pearson Korelâsyon ve çoklu doğrusal Regresyon analizleri kullanılarak değerlendirilmiştir. Anova testi ikiden fazla bağımsız değişkenin, T-testi ise bir ya da iki bağımsız değişken açısından anlamlı farklılık olup olmadığını ifade etmektedir. Korelasyon analizi değişkenler arasındaki ilişkiyi, regresyon analizi ise bağımsız değişkenlerin bağımlı değişkenler üzerindeki etkisini test etmek için kullanılmaktadır.

Çalışmada kur riskinden korunan firmalara ve korunmayan firmalara farklı sorular sorulduğu için çalışmaya ait iki farklı model söz konusudur. Birinci modelde döviz kur riskinden korunmayan firmalarla bağımsız değişkenler yani tanımlayıcı sorular arasındaki ilişki incelenmiştir. Model 2'de de 
döviz kur riskinden korunan firmalarla bağımsız değişkenler yani tanımlayıcı sorular arasındaki ilişki incelenmiştir.

\section{BULGULAR}

Çalışmanın bu bölümünde dış ticaret yapan firmalara uygulanan anket ile toplanan verilerin analizine dair bulgulara yer verilmiştir. Araştırma hipotezlerini test etmek amacıyla Anova ve T-testi, Pearson Korelâsyon ve çoklu doğrusal Regresyon analizleri yapılmıştır. Ayrıca değişkenlerin tanımlayıcı istatistik bilgilerine yer verilmiştir.

Çalışmada firmalara ait tanımlayıcı değişkenler Tablo 1'de yer almaktadır.

Tablo 1. Değiş̧kenlere Ait Tanımlayıcı Değiş̧kenler

\begin{tabular}{|c|c|c|c|}
\hline Sorular & Cevaplar & Frekanslar (N) & Yüzde(\%) \\
\hline \multirow{4}{*}{ Firma Faaliyet Süresi } & $1-5 \mathrm{y} 1 \mathrm{l}$ & 8 & 14,5 \\
\hline & $6-10 \mathrm{y} 1 \mathrm{l}$ & 12 & 21,8 \\
\hline & 10 yıl üstü & 35 & 63,6 \\
\hline & Toplam & 55 & 100,0 \\
\hline \multirow{4}{*}{ İşletme Aktif Büyüklüğü } & $250.000-1.000 .000 \mathrm{TL}$ & 10 & 18,2 \\
\hline & $1.000 .000-10.000 .000 \mathrm{TL}$ & 25 & 45,5 \\
\hline & 10.000 .000 TL üzeri & 20 & 36,4 \\
\hline & Toplam & 55 & 100,0 \\
\hline \multirow{5}{*}{ İşletme Faaliyet Türü } & Üretim & 13 & 23,6 \\
\hline & Ticaret & 15 & 27,3 \\
\hline & Üretim ve Ticaret & 19 & 34,5 \\
\hline & Ticaret ve Hizmet & 8 & 14,5 \\
\hline & Toplam & 55 & 100,0 \\
\hline \multirow{4}{*}{ Eğitim Seviyesi } & Lise & 13 & 23,6 \\
\hline & Üniversite & 38 & 69,1 \\
\hline & Lisansüstü & 4 & 7,3 \\
\hline & Toplam & 55 & 100,0 \\
\hline \multirow{3}{*}{ Dış Ticaret Faaliyeti } & İhracat & 19 & 34,5 \\
\hline & İthalat-İhracat & 36 & 65,5 \\
\hline & Toplam & 55 & 100,0 \\
\hline \multirow{5}{*}{ Faaliyetlerinde Dış Ticaret Oranı } & $\% 1-\% 25$ & 19 & 34,5 \\
\hline & $\% 26-\% 50$ & 14 & 25,5 \\
\hline & $\% 51-\% 75$ & 9 & 16,4 \\
\hline & $\% 75-\% 100$ & 13 & 23,6 \\
\hline & Toplam & 55 & $\mathbf{1 0 0 , 0}$ \\
\hline \multirow{4}{*}{ İşletme Hukuki Yapısı } & A.Ş & 16 & 29,1 \\
\hline & Ltd.Ştd & 28 & 50,9 \\
\hline & Şahıs Şirketi & 11 & 20,0 \\
\hline & Toplam & 55 & $\mathbf{1 0 0 , 0}$ \\
\hline \multirow{5}{*}{ Dış Ticaret Para Birimi } & Dolar & 7 & 12,7 \\
\hline & Dolar ve Euro & 27 & 49,1 \\
\hline & TL ve Dolar & 6 & 10,9 \\
\hline & TL-Dolar-Euro & 15 & 27,3 \\
\hline & Toplam & 55 & 100,0 \\
\hline \multirow{3}{*}{ Döviz Takip Sıklı̆̆ı } & Gün içinde sürekli & 43 & 78,2 \\
\hline & Günde bir kez & 12 & 21,8 \\
\hline & Toplam & 55 & 100,0 \\
\hline \multirow{3}{*}{ Döviz Riskinden Korunma } & Evet & 21 & 38,2 \\
\hline & Hayır & 34 & 61,8 \\
\hline & Toplam & 55 & 100,0 \\
\hline
\end{tabular}


Firmaların çoğunun 10 yıldan uzun süre faaliyet gösterdiği yani sektöre yeni giren işletmeler olmadığı, aktif büyüklükleri 1 milyon TL'den fazla, hem imalatçı hem de imalatçı ve ihracatçı oldukları, dış ticaretlerinin toplam faaliyetlerindeki payı \% 50'den az olduğu, sermaye şirketi olduğu, ticari faaliyetlerinde döviz olarak Dolar ve Euro kullandığı ve döviz riskinde herhangi bir korunma yöntemlerine sahip olmadığı görülmektedir. Anket çalışmasına katılan firma yöneticilerinin \% 50 'sinden fazlası lisans mezunu olup döviz kurlarını günlük takip etmektedirler.

Çalışmada firmaların döviz kur riskinden korunma yöntemleri araştırıldığı için döviz kur riski koruma yöntemi olan ve olmayan firmalara aynı soruların sorulması analizde karşılaştırma açısından sağl1klı sonuçlar vermeyecektir. Bu nedenle döviz kur riski koruma yöntemi olan ve olmayan firmalara ayrı sorular sorulmuştur. Ayrı sorular sorulduğu için döviz kur riskinden korunan ve korunmayan firmalar olarak analiz 2 modelde gerçekleştirilecektir.

Öncelikle modellerin güvenilirlik sonuçlarına bakılmıştır.

Tablo 2. Güvenilirlik Test Sonuçları

\begin{tabular}{|c|c|}
\hline Modeller & Cronbach's Alpha Değeri \\
\hline Döviz Riskinden Korunan Firmalar & 0,706 \\
\hline Döviz Riskinden Korunmayan Firmalar & 0,686 \\
\hline
\end{tabular}

Her iki modelde de güvenilirliğin \% 60’ın üzerinde olması ölçeklerin yüksek derecede güvenilir olduklarını göstermektedir.

Çalışmada döviz kur riskinden korunan ve korunmayan firmalara sorulan anket sorularının cevapları faktör analizi vasıtasıyla tek faktör haline getirilmiştir. Çalışmada sınanan hipotezler şunlardır:

$\mathbf{H}_{0}$ : Döviz kur riskinden korunan firmalar demografik değişkenler arasında ilişki vardır.

$\mathbf{H}_{1}$ : Döviz kur riskinden korunmayan firmalar demografik değişkenler arasında ilişki vardır.

Bu kısımda çalışmada yer alan ANOVA testi sonuçları sırayla gösterilmektedir. Anova test sonuçlarından sadece anlamlı farklılık gösteren değişkenler tablolaştırılmıştır. Tablolaştırılmayan değişkenler arasında anlamlı farklılık bulunmamaktadır.

Tablo 3. Firma Faaliyet Süresine Göre Döviz Kuru Riskinden Korunan Firmaların ANOVA Testi Sonuçları

\begin{tabular}{|c|c|c|c|c|c|c|c|}
\hline \multicolumn{3}{|c|}{ Değișkenler } & Kareler toplamı & df & Kareler ortalamasi & $\mathbf{F}$ & Anlamlılık \\
\hline \multirow{3}{*}{ Evet_1 } & \multirow{3}{*}{$\begin{array}{c}\text { Firma Faaliyet } \\
\text { Süre }\end{array}$} & Grup içi & 4,504 & 2 & 2,252 & 4,799 & ,021 \\
\hline & & Gruplar & 8,448 & 18 &, 469 & & \\
\hline & & Toplam & 12,952 & 20 & & & \\
\hline \multirow{3}{*}{ Evet_2 } & \multirow{3}{*}{$\begin{array}{c}\text { Firma Faaliyet } \\
\text { Süre }\end{array}$} & Grup içi & ,310 & 2 &, 155 & , 129 & ,880 \\
\hline & & Gruplar & 21,574 & 18 & 1,199 & & \\
\hline & & Toplam & 21,884 & 20 & & & \\
\hline \multirow{3}{*}{ Evet_3 } & \multirow{3}{*}{$\begin{array}{c}\text { Firma Faaliyet } \\
\text { Süre }\end{array}$} & Grup içi & 6,908 & 2 & 3,454 & 6,280 & ,009 \\
\hline & & Gruplar & 9,901 & 18 &, 550 & & \\
\hline & & Toplam & 16,810 & 20 & & & \\
\hline
\end{tabular}


Firma faaliyet süresine ilişkin görüşleri Evet_1 olanların $(p=.021<0,05)$ ve Evet_3 olanların $(\mathrm{p}=.009<0,05)$ olduğundan dolayı firma faaliyet süresi ile anlamlı farklılık olduğu görülmüsstür. Farklılığın hangi firma faaliyet süresinde olduğunu belirlemek amaciyla Tukey testi ile analiz edilmiş ve analiz sonuçları tablo 4’te verilmiştir.

Tablo 4. Evet_1 ve Evet_3’ün Firma Faaliyet Süresine göre Tukey Testi Sonucu

\begin{tabular}{|c|c|c|c|c|c|c|c|}
\hline & \multirow{2}{*}{\multicolumn{2}{|c|}{ Değiş̧kenler }} & \multirow{3}{*}{$\begin{array}{c}\begin{array}{c}\text { Ortalama } \\
\text { Fark }\end{array} \\
-1,20\end{array}$} & \multirow{3}{*}{$\begin{array}{r}\text { Std. } \\
\text { Hata }\end{array}$} & \multirow{3}{*}{$\begin{array}{c}\text { Anlamlılık } \\
, 158\end{array}$} & \multicolumn{2}{|c|}{ \%95 Güven aralığı } \\
\hline & & & & & & \multirow{2}{*}{$\begin{array}{c}\text { Düşük } \\
-2,80\end{array}$} & \multirow{2}{*}{$\begin{array}{c}\text { Yüksek } \\
, 38\end{array}$} \\
\hline \multirow{6}{*}{$\underset{D}{\mathbb{D}^{\prime}}$} & \multirow{2}{*}{$1-5$ y1l } & $6-10$ yil & & & & & \\
\hline & & 10 yıl üstü &, 125 & ,513 & ,968 & $-1,18$ & 1,43 \\
\hline & \multirow{2}{*}{$6-10$ y1l } & $1-5$ y1l & 1,20 & 625 &, 158 &,- 38 & 2,80 \\
\hline & & 10 yıl üstü & $1,33^{*}$ & ,431 & ,016 &, 23 & 2,43 \\
\hline & \multirow{2}{*}{10 y1l üstü } & $1-5$ y1l &,- 12 &, 513 & ,968 & $-1,43$ & 1,18 \\
\hline & & $6-10$ yil & $-1,33$ & ,431 & ,016 & $-2,43$ &,- 23 \\
\hline \multirow{6}{*}{ 象 } & \multirow{2}{*}{$1-5 \mathrm{y} 1 \mathrm{l}$} & $6-10$ yil & 1,66 & ,677 &, 060 &,- 06 & 1,39 \\
\hline & & 10 yıl üstü & $1,96^{*}$ &, 556 & ,006 &, 54 & 1,38 \\
\hline & \multirow{2}{*}{$6-10 \mathrm{y} 11$} & $1-5$ yil & $-1,66$ & ,677 & ,060 & $-1,39$ & ,06 \\
\hline & & 10 y1l üstü & ,302 & ,466 & ,796 &,- 88 & 1,49 \\
\hline & \multirow{2}{*}{10 yıl üstü } & $1-5$ y1l & $-1,96$ &, 556 & ,006 & $-1,38$ &,- 54 \\
\hline & & $6-10$ yil &,- 302 & ,466 & ,796 & $-1,49$ &, 88 \\
\hline
\end{tabular}

* 0,05 anlamlılık düzeyinde anlamlı

Evet_l'in Firma Faaliyet Süresine ile Tukey testi sonucuna göre; Firma Faaliyet Süresine 6-10 yıl olanlar ile 10 yıl ve üzeri olanlar arasında evet_1 açısından \%133 farklılık göstermiştir. Evet_3'ün Firma Faaliyet Süresine ile Tukey testi sonucuna göre; Firma Faaliyet Süresine 1-5 y1l olanlar ile 10 yıl ve üzeri olanlar arasında evet_3 açısından \%196 farklılık göstermiştir. Sonuç olarak evet_1 ve evet_3 ile firma büyüklüğü arasında anlamlı farklılık ortaya çıkmıştır.

Tablo 5. Firma Büyüklüğüne Göre Döviz Kuru Riskinden Korunmayan Firmaların ANOVA Testi Sonuçları

\begin{tabular}{|c|c|c|c|c|c|c|c|}
\hline \multicolumn{3}{|c|}{ Değişkenler } & Kareler toplamı & df & $\begin{array}{c}\text { Kareler } \\
\text { ortalaması }\end{array}$ & $\mathbf{F}$ & Anlamlılık \\
\hline \multirow{3}{*}{ Hayır_1 } & \multirow{3}{*}{$\begin{array}{c}\text { Firma } \\
\text { Büyüklüğüu }\end{array}$} & Grup içi & 3,97 & 2 & 1,986 & 4,360 & ,021 \\
\hline & & Gruplar & 14,12 & 31 &, 456 & & \\
\hline & & Toplam & 18,09 & 33 & & & \\
\hline \multirow{3}{*}{ Hayır_2 } & \multirow{3}{*}{$\begin{array}{c}\text { Firma } \\
\text { Büyüklüğüi }\end{array}$} & Grup içi &, 162 & 2 &, 081 & ,261 &, 772 \\
\hline & & Gruplar & 9,61 & 31 & 310 & & \\
\hline & & Toplam & 9,77 & 33 & & & \\
\hline
\end{tabular}

Döviz kuru riskinden korunmayanların Firma büyüklüğüne ilişkin görüşleri Hayır_1 olanların $(\mathrm{p}=.021<0,05)$ firma büyüklüğü ile anlamlı farklılık olduğu görülmüştür. Farklılığın hangi eğitim 
durumunda olduğunu belirlemek amacıyla Tukey testi ile analiz edilmiş ve analiz sonuçları tablo 6'da verilmiştir.

Tablo 6. Hayır_1'in Firma Büyüklügüne Göre Tukey Testi Sonucu

\begin{tabular}{|c|c|c|c|c|c|c|c|}
\hline \multirow{2}{*}{\multicolumn{3}{|c|}{ Değişkenler }} & \multirow{3}{*}{$\begin{array}{c}\begin{array}{c}\text { Ortalama } \\
\text { Fark }\end{array} \\
-, 481\end{array}$} & \multirow{3}{*}{$\begin{array}{c}\begin{array}{c}\text { Std. } \\
\text { Hata }\end{array} \\
, 28939\end{array}$} & \multirow{3}{*}{$\begin{array}{c}\text { Anlamlılık } \\
, 235\end{array}$} & \multicolumn{2}{|c|}{ \%95 Güven aralığı } \\
\hline & & & & & & \multirow{2}{*}{$\begin{array}{l}\text { Düşükk } \\
-1,19\end{array}$} & \multirow{2}{*}{$\begin{array}{c}\text { Yüksek } \\
, 2306\end{array}$} \\
\hline \multirow{6}{*}{$\stackrel{-1}{\vec{Z}}$} & \multirow{2}{*}{$\begin{array}{c}250.000- \\
1.000 .000 \mathrm{TL}\end{array}$} & $\begin{array}{c}1.000 .000- \\
10.000 .000 \mathrm{TL}\end{array}$ & & & & & \\
\hline & & $\begin{array}{c}10.000 .000 \mathrm{TL} \\
\text { üzeri }\end{array}$ & ,312 & ,32798 & ,612 &,- 494 & 1,1197 \\
\hline & \multirow{2}{*}{$\begin{array}{c}1.000 .000- \\
10.000 .000 \mathrm{TL}\end{array}$} & $\begin{array}{c}250.000- \\
1.000 .000 \mathrm{TL}\end{array}$ & ,481 & ,28939 & ,235 &,- 230 & 1,1939 \\
\hline & & $\begin{array}{c}10.000 .000 \mathrm{TL} \\
\text { üzeri }\end{array}$ &, $7941^{*}$ & ,27824 & ,020 & , 109 & 1,4789 \\
\hline & \multirow{2}{*}{$\begin{array}{c}10.000 .000 \mathrm{TL} \\
\text { üzeri }\end{array}$} & $\begin{array}{c}250.000- \\
1.000 .000 \mathrm{TL}\end{array}$ &,- 312 & ,32798 & ,612 & $-1,11$ & ,4947 \\
\hline & & $\begin{array}{c}1.000 .000- \\
10.000 .000 \mathrm{TL}\end{array}$ &,- 7941 & ,27824 & ,020 & $-1,47$ &,- 1093 \\
\hline
\end{tabular}

* 0,05 anlamlılık düzeyinde anlamlı

Hayır_1'infirma büyüklüğü ile Tukey testi sonucuna göre; firma büyüklüğü 10.000.000 TL ve üzeri olanlar ile 1.000.000 - 10.000.000 TL olanlar arasında hayır_1 açısından \%79 farklılık göstermiştir. Sonuç olarak hayır_1 ile firma büyüklüğü arasında anlamlı farklılık ortaya çıkmıştır. Yani firmaların büyüklüğü, döviz kur riskinden korunmama açısından önem teşkil etmektedir.

Tablo 7. Dış Ticaret Oranına Göre Döviz Kuru Riskinden Korunmayan Firmaların ANOVA Testi Sonuçları

\begin{tabular}{|l|c|l|c|c|c|c|c|}
\hline \multicolumn{3}{|c|}{ Değişkenler } & Kareler toplamı & df & Kareler ortalamas & F & Anlamlılık \\
\hline \multirow{2}{*}{ Hayır_1 } & \multirow{3}{*}{$\begin{array}{c}\text { Dış Ticaret } \\
\text { Oranı }\end{array}$} & Grup içi & 4,53 & 3 & 1,512 & 3,344 &, 032 \\
\cline { 3 - 8 } & & Gruplar & 13,56 & 30 &, 452 & & \\
\cline { 3 - 8 } & & Toplam & 18,09 & 33 & & & \\
\hline \multirow{3}{*}{ Hayır_2 } & \multirow{2}{*}{$\begin{array}{c}\text { Dış Ticaret } \\
\text { Oranı }\end{array}$} & Grup içi & 1,25 & 3 &, 418 & 1,471 &, 242 \\
\cline { 3 - 8 } & & Gruplar & 8,52 & 30 &, 284 & & \\
\cline { 3 - 8 } & & Toplam & 9,77 & 33 & & & \\
\hline
\end{tabular}

Döviz kuru riskinden korunmayan firmaların, dış ticaret oranına ilişkin görüşleri Hayır_1 olanlar $(\mathrm{p}=.032<0,05)$ olduğundan dolayı dış ticaret oranı ile anlamlı farklılık olduğu görülmüştür. Farklılığın hangi dış ticaret oranında olduğunu belirlemek amacıyla Tukey testi ile analiz edilmiş ve analiz sonuçları tablo 8'de verilmiştir. 
Tablo 8. Hayır_l'in Dış Ticaret Oranına Göre Tukey Testi Sonucu

\begin{tabular}{|c|c|c|c|c|c|c|c|}
\hline & $\mathbf{D}$ & mler. & Ortalama & Std. & Anlambluk & $\% 95 \mathrm{G}$ & Aralığ \\
\hline & Deg & nler & Fark & Sapma & Anlamiılık & Düşük & Yüksek \\
\hline & & $\% 26-50$ &, 004 & ,29434 & 1,00 &,- 796 & ,804 \\
\hline & $\begin{array}{c}\% \\
1-25\end{array}$ & $\% 51-75$ & $-1,033$ & ,34718 & ,028 & $-1,977$ &,- 089 \\
\hline & & $\% 75-100$ &,- 016 & ,32476 & 1,00 &,- 899 & ,866 \\
\hline & & $\% 1-25$ &,- 004 & 29434 & 1,00 &,- 804 & ,796 \\
\hline & $\begin{array}{c}\% \\
26-50\end{array}$ & $\% 51-75$ & $-1,037$ & ,38328 &, 051 & $-2,079$ & ,004 \\
\hline$=$ & & $\% 75-100$ &,- 020 & 36309 & 1,00 & $-1,008$ & ,966 \\
\hline $\bar{\Xi}$ & & $\% 1-25$ & $1,033^{*}$ & ,34718 &, 028 & ,089 & 1,977 \\
\hline & $\begin{array}{c}\% \\
51-75\end{array}$ & $\% 26-50$ & 1,037 & ,38328 &, 051 &,- 004 & 2,079 \\
\hline & & $\% 75-100$ & 1,016 & 40711 & ,081 &,- 090 & 2,123 \\
\hline & $\%$ & $\% 1-25$ &, 016 &, 32476 & 1,00 &,- 866 & ,899 \\
\hline & $75-$ & $\% 26-50$ &, 020 & 36309 & 1,00 &,- 966 & 1,008 \\
\hline & 100 & $\% 51-75$ & $-1,016$ & ,40711 & 081 & $-2,123$ & ,090 \\
\hline
\end{tabular}

* 0,05 anlamlılık düzeyinde anlamlı

Hayır_1'indış ticaret oranı ile Tukey testi sonucuna göre; diş ticaret oranı \%51-75 olanlar ile \%1-25 olanlar arasında hayır_1 açısından \%103 farklılık göstermiştir. Sonuç olarak hayır_1 ile dış ticaret oranı arasında anlamlı farklılık ortaya çıkmıştır. Yani firmaların satış hasılatı içindeki dış ticaret payı arttıkça firmaların kur riskinde korunmama durumu farklılık göstermektedir.

Tablo 9. Firmanın Hukuki Yapısına Göre Döviz Kuru Riskinden Korunmayan Firmaların ANOVA Testi Sonuçları

\begin{tabular}{|c|c|c|c|c|c|c|c|}
\hline \multicolumn{3}{|c|}{ Değişkenler } & Kareler toplamı & df & Kareler ortalaması & F & Anlamlılık \\
\hline \multirow{2}{*}{ Hayır_1 } & \multirow{2}{*}{$\begin{array}{c}\text { Firma Hukuki } \\
\text { Yapı }\end{array}$} & Grup içi & 2,74 & 2 & 1,37 & 2,774 &, 048 \\
\cline { 3 - 8 } & & Gruplar & 15,34 & 31 &, 495 & & \\
\cline { 3 - 8 } & Toplam & 18,09 & 33 & & & \\
\hline \multirow{2}{*}{ Hayır_2 } & \multirow{2}{*}{$\begin{array}{c}\text { Firma Hukuki } \\
\text { Yapı }\end{array}$} & Grup içi &, 876 & 2 &, 438 & 1,526 &, 233 \\
\cline { 3 - 8 } & & Gruplar & 8,90 & 31 &, 287 & & \\
\cline { 3 - 8 } & & Toplam & 9,77 & 33 & & & \\
\hline
\end{tabular}

Döviz kuru riskinden korunmayan firmaların, firma hukuki yapısına ilişkin görüşleri hayır_1 olanlar $(\mathrm{p}=.048<0,05)$ olduğundan dolayı firma hukuki yapısı ile anlamlı farklılık olduğu görülmüştür. Farklı1ığın hangi dış ticaret oranında olduğunu belirlemek amacıyla Tukey testi ile analiz edilmiş ve analiz sonuçları tablo 10'da verilmiştir. 
Tablo 10. Hayır_1'in Firma Hukuki Yapısına Göre Tukey Testi Sonucu

\begin{tabular}{|c|c|c|c|c|c|c|c|}
\hline & Değiş & & Ortalama & Std. & Anlamlılık & $\begin{array}{r}\% 95 \\
\text { A } \\
\end{array}$ & $\begin{array}{l}\text { Güven } \\
\text { llığ }\end{array}$ \\
\hline & & & & & & Düsük & Yüksek \\
\hline & $\mathrm{S}$ & Ltd.Ştd &,- 675 & ,230 & ,031 & $-1,29$ &,- 055 \\
\hline & A.Ş & Şahıs şirketi &,- 843 & ,344 & ,095 & $-1,81$ & , 129 \\
\hline$=1$ & It $\mathrm{C}$ & A.Ş & $675^{*}$ & ,230 &, 031 &, 055 & 1,29 \\
\hline$\widehat{\Xi}$ & Ltd.Ştd & Şahıs şirketi &,- 168 & ,339 & ,949 & $-1,12$ & ,783 \\
\hline & Sahis & A.Ş & ,843 & ,344 & ,095 &,- 12 & 1,817 \\
\hline & Şirketi & Ltd.Ştd & , 168 & ,339 & ,949 &,- 783 & 1,121 \\
\hline
\end{tabular}

* 0,05 anlamll11k düzeyinde anlamlı

Hayır_1'infirma hukuki yapısı ile Tukey testi sonucuna göre; firma hukuki yapısı Ltd. Ştd. olanlar ile A.Ş olanlar arasında hayır_1 açısından \% 67 farklılık göstermiştir. Sonuç olarak hayır_1 ile firma hukuki yapısı arasında anlamlı farklılık ortaya çıkmıştır. Yani firmaların tüzel kiş̧iliklerine göre döviz kuru riskinden korunma durumu değişmektedir.

Tablo 11. Eğitim Durumuna Göre Döviz Kuru Riskinden Korunan Firmaların ANOVA Testi Sonuçları

\begin{tabular}{|c|c|c|c|c|c|c|c|}
\hline \multicolumn{3}{|c|}{ Değişkenler } & Kareler toplamı & df & Kareler ortalaması & $\mathbf{F}$ & Anlamlılık \\
\hline \multirow{3}{*}{ Evet_1 } & \multirow{3}{*}{$\begin{array}{l}\text { Eğitim } \\
\text { Durumu }\end{array}$} & Grup içi & 4,060 & 2 & 2,030 & 4,110 & ,034 \\
\hline & & Gruplar & 8,892 & 18 & ,494 & & \\
\hline & & Toplam & 12,952 & 20 & & & \\
\hline \multirow{3}{*}{ Evet_2 } & \multirow{3}{*}{$\begin{array}{l}\text { Ĕgitim } \\
\text { Durumu }\end{array}$} & Grup içi & 1,115 & 2 & ,558 & ,483 & ,625 \\
\hline & & Gruplar & 20,769 & 18 & 1,154 & & \\
\hline & & Toplam & 21,884 & 20 & & & \\
\hline \multirow{3}{*}{ Evet_3 } & \multirow{3}{*}{$\begin{array}{l}\text { Eğitim } \\
\text { Durumu }\end{array}$} & Grup içi & 1,631 & 2 & ,815 & ,967 & ,399 \\
\hline & & Gruplar & 15,179 & 18 & ,843 & & \\
\hline & & Toplam & 16,810 & 20 & & & \\
\hline
\end{tabular}

Döviz kuru riskinden korunan firmaların eğitim durumuna ilişkin görüşleri Evet_2 olanlar $(p=.625>0,05)$ ile Evet_3 olanlar $(p=.399>0,05)$ olduğundan anlamlı farklılık olmadığı sonucu ortaya çıkmıştır. Görüşü Evet_1 olanlar $(\mathrm{p}=.034<0,05)$ olduğundan dolayı eğitim durumu ile anlamlı farklılık olduğu görülmüştür. Farklılığın hangi eğitim durumunda olduğunu belirlemek amacıyla Tukey testi ile analiz edilmiş ve analiz sonuçları tablo 12 'de verilmiştir. 
Tablo 12. Evet_3'ün Eğitim Durumuna Göre Tukey Testi Sonucu

\begin{tabular}{|c|c|c|c|c|c|c|c|}
\hline & \multirow{2}{*}{\multicolumn{2}{|c|}{ Değişkenler }} & \multirow{2}{*}{$\begin{array}{c}\text { Ortalama } \\
\text { Fark }\end{array}$} & \multirow{2}{*}{$\begin{array}{l}\text { Std. } \\
\text { Hata }\end{array}$} & \multirow[t]{2}{*}{ Anlamlılık } & \multicolumn{2}{|c|}{$\begin{array}{c}\text { \%95 Güven } \\
\text { Aralığı }\end{array}$} \\
\hline & & & & & & Düșük & Yüksek \\
\hline \multirow{6}{*}{$\sum_{1}^{\infty}$} & \multirow{2}{*}{ Lise } & Üniversite & ,508 & ,398 & ,426 &,- 508 & 1,52 \\
\hline & & Lisansüstü &,- 729 & ,536 & ,383 & $-1,09$ & 640 \\
\hline & \multirow{2}{*}{ Üniversite } & Lise &,- 508 & ,398 & ,426 & $-1,52$ & ,508 \\
\hline & & Lisansüstü & $-1,23$ & ,447 & ,032 & $-1,37$ &,- 096 \\
\hline & \multirow{2}{*}{ Lisansüstü } & Lise &, 729 &, 536 &, 383 &,- 640 & 1,09 \\
\hline & & Üniversite & $1,23^{*}$ & ,447 & ,032 & ,096 & 1,37 \\
\hline
\end{tabular}

*0,05 anlamlılık düzeyinde anlamlı

Evet_3'ün Eğitim durumu ile Tukey testi sonucuna göre; eğitim durumu Lisansüstü olanlar ile Üniversite olanlar arasında Evet_3 açısından \%123 anlamlı farklılık sonucu ortaya çıkmıştır. Yani firmaların döviz kuru riskinden korunma durumu ankete katılan kişinin eğitim durumuna göre değişmektedir.

Tablo 13. Pearson Korelâsyon Sonuçları

\begin{tabular}{|c|c|c|}
\hline \multirow[b]{2}{*}{ Bağımsız Değişkenler } & \multicolumn{2}{|c|}{ Pearson Korelâsyon Katsayısı } \\
\hline & $\begin{array}{l}\text { Döviz Kuru Riskinden } \\
\text { Korunan Firmalar }\end{array}$ & $\begin{array}{l}\text { Döviz Kuru Riskinden } \\
\text { Korunmayan Firmalar }\end{array}$ \\
\hline Firma Faaliyet Süresi & $-0,418$ & $-0,351$ \\
\hline Firma Büyüklüğü &, $010 * *$ & $-0,183$ \\
\hline İşletme Faaliyet Türü & $-0,269$ & $-0,003 * * *$ \\
\hline Eğitim Durumu & $0,025 * *$ & $-0,096^{*}$ \\
\hline D1ş Ticaret Faaliyeti & $-0,339$ & $-0,097 *$ \\
\hline Diş Ticaret Oranına & 0,271 & 0,224 \\
\hline Firma Hukuki Yapısı & 0,231 & 0,359 \\
\hline Ticari Para Birimi & $0,094 *$ & 0,188 \\
\hline Döviz Takip S1klı̆̆ & $0,005 * * *$ & $0,005 * * *$ \\
\hline
\end{tabular}

Not: $* * *, * *, *$ önemlilik sırasıyla $\% 1, \% 5$ ve $\% 10$ anlamlılık düzeylerini ifade etmektedir.

Tablo 13’te korelasyon test sonuçları incelendiğinde; Döviz kur riskinde korunan firmaların açıklayıcı soruları ile firmaların ticari faaliyetlerinde kullandıkları para birimi ile aralarında \% 10 anlamlılık düzeyinde; firmaların aktif büyüklüğü ve yöneticilerin eğitim durumu ile aralarında \% 5 anlamlılık düzeyinde; döviz kuru takip sıklığı ile aralarında \% 1 anlamlılık düzeyinde güçlü bir ilişki vardır. Yani $\mathrm{H}_{0}$ hipotezi kabul edilmektedir.

Döviz kur riskinde korunmayan firmaların açıklayıcı soruları ile yöneticilerin eğitim durumları ve dış ticaret faaliyetleri arasında \% 10 anlamlılık düzeyinde; işletmelerin faaliyet türü ve döviz kuru takip sıklı̆ğ ile aralarında \% 1 anlamlılık düzeyinde güçlü bir ilişki vardır. Yani $\mathrm{H}_{1}$ hipotezi de kabul edilmektedir. 
Korelasyon test sonuçlarından elde edilen sonuçların sağlamlaştırılması için yapılacak Çoklu Regresyon analizine yönelik regresyon analiz sonuçları aşağıdaki gibidir:

Tablo 14. Model 1 İçin Regresyon Analizi Sonuçları

\begin{tabular}{|c|c|c|c|c|c|c|}
\hline $\begin{array}{c}\text { Bağımlı } \\
\text { Değişken }\end{array}$ & $\begin{array}{l}\text { Bağımsız } \\
\text { Değișken }\end{array}$ & B & $\begin{array}{c}\text { Standart } \\
\text { Hata }\end{array}$ & $\beta$ & $\mathbf{t}$ & $\mathbf{p}$ \\
\hline \multirow{10}{*}{$\begin{array}{c}\text { Döviz Kuru } \\
\text { Riskinden } \\
\text { Korunmayan } \\
\text { Firmalar }\end{array}$} & Sabit & 1,507 &, 806 & & 1,871 &, 074 \\
\hline & Firma Faaliyet Süresi &,- 256 &, 126 &,- 375 & $-2,036$ &, 048 \\
\hline & Firma Büyüklüğü &,- 089 &, 170 &,- 120 &,- 522 & 607 \\
\hline & İşletme Faaliyet Türü &, 037 &, 078 &, 109 &, 478 & 637 \\
\hline & Ĕgitim Durumu &,- 178 & 214 &,- 165 &,- 834 & ,413 \\
\hline & Dış Ticaret Oranına &, 093 &, 125 &, 177 & ,746 & ,463 \\
\hline & Firma Hukuki Yapısı & 276 & 109 & 600 & 2,524 & 019 \\
\hline & Ticari Para Birimi &, 190 & 092 & ,368 & 2,064 &, 050 \\
\hline & Döviz Takip Sıklığı & 087 & 070 & 228 & 1,247 & 224 \\
\hline & Riskten Korunma Durumu &,- 006 & ,232 &,- 005 &,- 027 & ,978 \\
\hline $\mathrm{R}=.679$ & $.461 \quad$ Düz. $\mathrm{R}^{2}=.259$ & & 049 & & & \\
\hline
\end{tabular}

Tablo 14 incelendiğinde, regresyon analizine dâhil edilen demografik değişkenler, Döviz Kuru Riskinden Korunmayan Firmalar \%25,9'unu açıklamaktadır. Regresyon analizinde oluşturulan araştırma modeli 1'de anlamlı ilişki ve etki ortaya çıkmıştır. Yapılan analizi grup bazında incelendiğinde, firma faaliyet süresinin $(\beta=-.37$; $p<0.048)$ Döviz Kuru Riskinden Korunmayan Firmalar üzerinde ters yönlü etkisi olduğu ortaya çıkmıştır. Diğer değişkenler incelendiğinde ise Firmanın hukuki yapısı $(\beta=.60 ; p<0.019)$, ticari para biriminin $(\beta=, 36 ; p<0.050)$ döviz kuru riskinden korunmayan firmalar üzerinde eş yönlü etkisi olduğu ortaya çıkmıştır.

Döviz kuru riskinden korunmayan firmalarda oluşacak 1 birim artış firma faaliyet süresinde \%37 azalışa neden olduğu sonucu ortaya çıkmıştır. Döviz kuru riskinden korunmayan firmalarda oluşacak 1 birim artış ticari para biriminde $\% 36$ ve firma hukuki yapısında $\% 60$ artışa neden olduğu sonucu ortaya çıkmıştır. Firmaların faaliyetlerindeki dış ticaret payı ve şirket türlerinin döviz kuru riskinden korunmaması ile arasında ilişki vardır. Bu durum dış ticaret hacmi düşük olan ve şirket türü ne olursa olsun döviz kuru riskinden korunma ihtiyacı olduğunu ifade edebilir.

Tablo 15. Model 2 İçin Regresyon Analizi Sonuçları

\begin{tabular}{|c|c|c|c|c|c|c|}
\hline $\begin{array}{c}\text { Bağımlı } \\
\text { Değişken }\end{array}$ & $\begin{array}{l}\text { Bağımsız } \\
\text { Değişken }\end{array}$ & B & $\begin{array}{l}\text { Standart } \\
\text { Hata }\end{array}$ & $\beta$ & $\mathbf{t}$ & $\mathbf{p}$ \\
\hline \multirow{10}{*}{$\begin{array}{c}\text { Döviz Kuru } \\
\text { Riskinden } \\
\text { Korunan } \\
\text { Firmalar }\end{array}$} & Sabit & 2,062 & 2,084 & & ,989 & ,344 \\
\hline & Firma Faaliyet Süresi & , 178 & 412 & ,166 & ,433 & ,674 \\
\hline & Firma Büyüklüğü &,- 133 & ,367 &,- 127 &,- 363 &, 723 \\
\hline & İşletme Faaliyet Türü &,- 379 & 250 &,- 663 & $-1,520$ & ,157 \\
\hline & Eğitim Durumu &,- 106 & 330 &,- 088 &,- 320 & 755 \\
\hline & Dış Ticaret Oranına &,- 362 & 290 &,- 412 & $-1,249$ & ,237 \\
\hline & Firma Hukuki Yapısı & 276 & ,225 & ,436 & 1,229 & ,245 \\
\hline & Ticari Para Birimi & ,082 & ,186 & ,119 & ,440 & ,669 \\
\hline & Döviz Takip Sıklığı & 266 &, 159 & ,640 & 1,672 &, 123 \\
\hline & Riskten Korunma Durumu & ,220 & 487 &, 112 & ,453 & 659 \\
\hline
\end{tabular}


Tablo 15 incelendiğinde, demografik değişkenler ve Döviz Kuru Riskinden Korunan Firmalar arasında istatistiksel olarak bir regresyon modeli oluşturulamamıştır $(F=1,035 ; \mathrm{p}<0.470)$.

Regresyon analizine dâhil edilen demografik değişkenler, döviz kuru riskinden korunan firmaların kur riskinden korunma yöntemlerinin \%1,6'sını açıklamaktadır. Regresyon analizinde oluşturulan araştırma modeli 2'de anlamlı ilişki ve etki ortaya çıkmamıştır.

\section{SONUÇ VE TARTIŞMA}

Ülkelerin gelişimi için dış ticaretin büyük önem arz ettiği bilinmektedir. Bu nedenle ülkelerde dış ticaret yapan firmaların karşılaştıkları sorunlarla alakalı yapılmış birçok çalışma olduğu görülmektedir. Dış ticaret yapan firmaların karşılaştıkları en önemli sorunlardan biri, esnek döviz kur sistemini benimseyen ülkelerde kur riskidir. Kur riskinin kontrol altında tutulabilmesi türev ürünler kullanma, sigorta gibi bazı korunma yöntemleri ile mümkündür.

$\mathrm{Bu}$ nedenle çalışmada Malatya ilinde faaliyet gösteren dış ticaret firmalarının tanımlayıcı yapıları ile kur riskinden korunma/korunmama arasındaki ilişki araştırılmıştır. Bu amaçla Malatya ilinde dış ticaret yapan 55 firmaya anket çalışması uygulanmıştır. Yöntem olarak Pearson korelâsyon ve çoklu doğrusal regresyon analizleri tercih edilmiştir.

Analizler sonucunda;

Çalışmanın $\mathrm{H}_{0}$ ve $\mathrm{H}_{1}$ hipotezleri, demografik değişkenlerin döviz kuru riskinden korunmayan ve döviz kuru riskinden korunan firmalar üzerindeki etkisini araştırmak amacıyla oluşturulan modellere göre, doğrusal çoklu regresyon analizi sonuçlarında demografik değişkenlerin döviz kuru riskinden korunan firmalar üzerinde etkisinin olmadığı fakat işletmenin hukuki yapısı ile \% 60, ticari para birimi ile \% 36 aynı yönde etkilediği, işletme faaliyet süresini \%37 ters yönlü etkilediği sonucu ortaya çıkmıştır. Döviz kur riskinden korunmayan firmaların demografik değişkenlerden etkilenmediği görülmektedir. İşletmelerin kurumsal açıdan profesyonelleştikçe kur riskinden korunma konusunda daha bilinçli olabileceği, dış ticaret faaliyetlerinde kullandıkları döviz kuruna göre döviz kur riski politikalarını belirleyebilecekleri söylenebilir. İşletme faaliyet süresi arttıkça kur riskinden korunma eğiliminin azaldığ 1 görülmektedir. Bu da işletmelerin deneyimi arttıkça kur politikaları konusunda daha öngörülü olabilecekleri ile açıklanabilir.

Döviz kuru riskinden korunmayan ve döviz kuru riskinden korunan firmaların demografik değişkenler arasındaki anlamlılık ilişkisini belirlemeye yönelik yapılan incelemelerde;

- Firma faaliyet süresine göre döviz kuru riskinden korunan firmalar, faaliyet süresi 6-10 y1l olanlar ile 10 yıl ve üzeri olanlar arasında evet-1 açısından \%133 ve firma Faaliyet Süresine 1-5 yıl olanlar ile 10 yıl ve üzeri olanlar arasında evet_3 açısından \% 196 farklılık göstermiştir

• Firmanın büyüklüğüne göre döviz kuru riskinden korunmayan, firma büyüklüğü 10.000 .000 TL ve üzeri olanlar ile 1.000.000 - 10.000.000 TL olanlar arasında hayır_1 açısından \% 79 farklılık 
göstermiştir. İncelemeler sonucunda, döviz kuru riskinden korunmayan firmalar ile firma büyüklüğü arasında pozitif ilişki olduğu sonucuna varılmıştır.

- Firmanın eğitim durumuna göre döviz kuru riskinden korunan, eğitim durumu Lisansüstü olanlar ile Üniversite olanlar arasında Evet_3 açısından \% 123 anlamlı farklılık sonucu ortaya çıkmıştır. İncelemeler sonucunda, firma eğitim durumu arttıkça döviz kuru riskinden korunmaya yönelik eğilimde artış olduğunu yani döviz kuru riskinden korunan firmalar ile firma eğitim durumu arasında pozitif ilişki olduğu sonucuna varılmıştır.

- Firmanın diş ticaret oranına göre döviz kuru riskinden korunmayan, dış ticaret oranı \%51-75 olanlar ile \%1-25 olanlar arasında hayır_1 açısından \% 103 farklılık göstermiştir İncelemeler sonucunda, dış ticaret oranı arttıkça döviz kuru riskinden korunmamada artış olduğunu yani döviz kuru riskinden korunmayan firmalar ile firma dış ticaret oranı arasında pozitif ilişki olduğu sonucuna varılmıştır. Firmaların dış ticaret hacminin artması durumunda daha fazla yabancı para cinsinden işlem yapacağ için kur riskinden korunma tedbirlerini daha çok hayata geçirdiklerini göstermektedir.

- Firmanın hukuki yapısına göre döviz kuru riskinden korunmayan, firma hukuki yapısı 1td. şti. şirket olanlar ile a.ş. olanlar arasında hayır_1 açısından \% 67 farklılık göstermiştir. İncelemeler sonucunda, firma hukuki yapısı arttıkça döviz kuru riskinden korunma durumunun artış olduğu yani döviz kuru riskinden korunmayan firmalar ile firma hukuki yapısı arasında pozitif ilişki olduğu sonucuna varılmıştır.

- Firmanın hukuki yapısına göre kur değişimi, şahıs şirketi olanlar ile A.Ş olanlar arasında \%56 anlamlı farkl11ık olduğu görülmüştür. İncelemeler sonucunda, firma kurumsallık düzeyi değiştikçe farklı döviz kurları kullanmalarında artış olduğu yani farklı döviz kuru kullanımı firma hukuki yapısı arasında pozitif ilişki olduğu sonucuna varılmıştır.

Korelasyon analizi sonucunda; Döviz kur riskinde korunan firmaların açıklayıcı soruları ile firmaların ticari faaliyetlerinde kullandıkları para birimi ile aralarında \% 10 anlamlılık düzeyinde; firmaların aktif büyüklüğü ve yöneticilerin eğitim durumu ile aralarında \% 5 anlamlılık düzeyinde; döviz kuru takip sıklı̆̆ı ile aralarında \% 1 anlamlılık düzeyinde güçlü bir ilişki vardır.

Döviz kur riskinden korunmayan firmaların açıklayıcı soruları ile yöneticilerin eğitim durumları ve dış ticaret faaliyetleri arasında \% 10 anlamlılık düzeyinde; işletmelerin faaliyet türü ve döviz kuru takip sıklığı ile aralarında \% 1 anlamlılık düzeyinde güçlü bir ilişki vardır. Bu sonuçlara göre hem $\mathrm{H}_{0}$ hem de $\mathrm{H}_{1}$ hipotezleri de kabul edilmektedir. Yani döviz kur riskinden korunmayan firmalar açısından yöneticilerin eğitim seviyesi, kur takip sıklı̆̆ı ve faaliyet türleri bir önem arz etmemektedir.

Regresyon analizi sonuçlarına göre ise; regresyon analizine dâhil edilen demografik değişkenler, döviz kuru riskinden korunmayan firmaların \%25,9'unu açıklamaktadır. Regresyon analizinde oluşturulan araştırma modeli 1'de anlamlı ilişki ve etki ortaya çıkmıştır. Yapılan analiz grup bazında incelendiğinde, firma faaliyet süresini döviz kuru riskinden korunmayan firmalar 
üzerinde ters yönlü etkisi olduğu ortaya çıkmıştır. Diğer değişkenler incelendiğinde ise firmanın hukuki yapısı, ticari para biriminin döviz kuru riskinden korunmayan firmalar üzerinde eş yönlü etkisi olduğu ortaya çıkmıştır.

Demografik değişkenler ve döviz kuru riskinden korunan firmalar arasında istatistiksel olarak bir regresyon modeli oluşturulamamıştır. Demografik değişkenlerin döviz kur riskinden korunan firmalar üzerinde etkili olmadığı sonucuna ulaşılmıştır.

Firmaların döviz kur riskinden korunmak için firmaların faaliyet süresi ile döviz kur riskinden korunmama arasında ters yönlü ilişki olması, özellikle sektörde uzun süre faaliyet gösteren firmaların geleneksel yöntemlerle kur riskinden korunmayı tercih ettikleri sonuçları ortaya çıkmıştır. Ancak bu firmaların da yeni yöntemleri benimsemeleri gerekmektedir. Firmaların şirket türü olarak kurumsallaşmalarının kur riskinden korunma ile arasında ilişki olduğu, bu nedenle kurumsal gelişimlerine dikkat etmeleri gerekmektedir. Ayrıca ticari para birimi ile kur riskinde korunmama arasında ilişki vardır. Yani özellikle konvertibl döviz olarak bilinen Dolar ve Euro'nun firmalar tarafından daha sık takip edildiği, bunlar dışındaki dövizlerde kur riskinden korunmanın daha zor olabileceği söylenebilir.

Büyük firmaların kur riskinden korunma arasında doğru orantılı ilişki vardır. Küçük firmaların da kur riskinden korunma konusuna önem göstermeleri firma için önem arz edecektir. Ankete katılan firma yöneticilerinin eğitim durumları ile kur riskinden korunma arasında ilişki vardır. Yani eğitim durumu lisans/lisansüstü olan yöneticilerin özellikle finans dersleri almasının kur riskinde korunma konusunda bilgi sahibi olmalarına neden olmaktadır. Dövizdeki değişimleri daha fazla takip edenlerin kur riskinde korunma ile arasında ilişki olduğu bilinmektedir. Dış ticaret yapan firmaların dünya piyasalarını ve kur hareketlerini daha güncel takip etmeleri gerekmektedir.

Çalışmanın sadece Malatya ilinde dış ticaret faaliyeti yapan işletmelere uygulanması çalışmanın kısıtı olarak ifade edilebilir. İlerleyen çalışmalarda örneklem il sayısı arttırılarak çalışma geliştirilebilir.

\section{KAYNAKÇA}

Aksu, D. (2016) İmalat Sektöründe Kur Riskinin Birincil ve İkincil Etkileri Ve Kur Riskine Karş1 Çözüm Önerileri, Muhasebe ve Finansman Dergisi, Sayı:71, s: 149-164.

Aksüyek, H., Yılmaz, HB (2017) Kur Riskinin İnşaat Projeleri Üzerindeki Etkisi ve Korunma Yöntemleri, Ulak Bilge Sosyal Bilimler Dergisi, Cilt: 5, Sayı:9, s: 179-198.

Allayannis, G., Ofek, E. (2001) Exchange Rate Exposure, Hedging, and The Use Of Foreign Currency Derivatives, Journal Of International Money and Finance, Cilt: 20, Say1: 2, s: 273-296.

Aypek, N., Kayahan, C. (2010) Kur Riskinden Korunmada Range Forward Kullanımı, Gazi Üniversitesi Ticaret ve Turizm Eğitim Fakültesi Dergisi, Sayı: 1, s: 1-17. 
Çıtak, N., Kurt, F. (2020) İhracat Firmalarında Riskten Korunma Aracı Olarak Türev Ürünlerin Kullanımı, Muhasebe Enstitüsü Dergisi, Sayı;62, s;11-22.

Çiftci, F., Yıldız, R. (2013) Dış Ticarette Kur Riski Yönetimi: Temsili Bir Türk Dış Ticaret Firması İçin Uygulama Örnekleri. Finansal Araştırmalar ve Çalışmalar Dergisi, Cilt: 5, Sayı: 9, s: 93 112.

Eun, C. S., Resnick, B. G. (1988) Exchange rate Uncertainty, Forward Contracts, and International Portfolio Selection, The Journal of Finance, Cilt: 43, Say1: 1, s: 197-215.

Gonzalez, L. O., Bua, M. V., Lopez, S. F., Santomil, P. D. (2010) Foreign Debt As A Hedging Instrument Of Exchange Rate Risk: A New Perspective, The European Journal of Finance, Cilt: 16, Say1: 7, s: 677-710.

Investopedia (2021) Range Forward, Erişim Linki: https://www.investopedia.com/terms/r/rangeforward-contract.asp, Erişim tarihi: 13.12.2021.

Kayahan, C., Akçay, U. M. B., Memiş, U. C., Yürükoğlu, U. Ö. Ö. (2010) Türk Reel Sektörünün Kur Riskinden Korunmada Opsiyon Kullanımı Ve Algılanan Volatilitenin Korunma Maliyetlerine Etkileri, Süleyman Demirel Üniversitesi İktisadi ve İdari Bilimler Fakültesi Dergisi, Cilt: 15, Say1: 1, s: 521-537.

Ketboğa, M. (2020) Dış Ticaretin Yapısal Sorunları, Bu Sorunların Firmaların Faaliyetleri Üzerindeki Etkileri: Malatya Örneği, İnönü Üniversitesi Sosyal Bilimler Enstitüsü Doktora Tezi.

Kim, SS, Chung, J., Hwang, J. H., Pyun, J. H. (2020) Döviz Kuru Riskinden Korunmada Dış Borcun Etkinliği: Çok Uluslu Şirketler ve İhracatçı Firmalar, Pacific-Basin Finance Journal, Sayı: 64 , s: $1-16$.

Kutukız, D. (2005) Turizm Sektöründe Döviz Riski ve Korunma Yöntemleri, Muhasebe ve Finansman Dergisi, Say1: 28, s: 198-207.

Papaioannou, M. G. (2006) Exchange Rate Risk Measurement and Management: Issues And Approaches For Firms, IMF Working Paper Say1: 06/255, s: 3-21.

Sezer, S., Canpolat, K. (2017) Firma Mevduatları ve Dış Ticaret Açısından Kur Riskinin Yönetilmesinde Türev Ürünlerin Kullanımı, Paradoks Ekonomi Sosyoloji ve Politika Dergisi, Cilt: 13, Say1: 1, s: 29-46.

Ünal, O., Altın, H. (2010) Döviz Kur Riski İle Şirket Değeri Arasındaki İlişkinin İMKB Otomotiv Sektöründe Analizi, Dumlupınar Üniversitesi Sosyal Bilimler Dergisi, Cilt;1, Say1;26, s;277287. 